\title{
Income Distribution in the Chinese Economy: Recent Trends and Challenges
}

\author{
Dr. Li Tan \\ School of Social Sciences, Kean University \\ 1000 Morris Ave., Union, NJ 07083, USA \\ Tel: 1-908-737-4153 E-mail: litan@Kean.edu
}

Received: June 21, 2011

Accepted: July 27, 2011 Published: January 1, 2012

doi:10.5539/ass.v8n1p3

URL: http://dx.doi.org/10.5539/ass.v8n1p3

\begin{abstract}
This paper examines the recent trends in regional income disparity and urban-rural income inequality in the Chinese economy. It finds that the income disparity between the eastern and western region had declined, but the urban-rural income inequality continued to rise in all four regions during the period under consideration. Moreover, the urban-rural income disparity increased more rapidly in the eastern region than in the western region, which was attributable to a slowdown of rural income growth in the eastern region. From a policy perspective, it is important to develop a dynamic agricultural sector to enable faster growth of rural household income.
\end{abstract}

Keywords: Income distribution, Chinese economy, Regional income disparity, Urban-rural income inequality, Per capita GDP, Household income

\section{Introduction}

Income distribution has been an important aspect of economic development, especially for the 'middle-income' developing economies. The Chinese economy has expanded at an extraordinary pace in the past three decades, with an average real GDP growth of around $10 \%$ per annum. Consequently, the country's per capita PPP gross nation income increased from US\$340 in 1978 to US\$6,010 in 2008 (World Bank, 2010), which turned China into a lower-middle-income economy. Rapid increase in national income has also greatly reduced the poverty level in China. The proportion of rural population in absolute poverty fell to $2.5 \%$ in 2005 (World Bank, 2010). However, alongside the rapid GDP growth, income distribution in China has deteriorated continuously. As broadly observed, the widening income gap has posted considerable challenges to the sustainability of the Chinese growth in longer terms.

The relationship between an economy's development levels and its income distribution is a complex issue and the past experiences varied among economies. The well-known "inverted U" hypothesis (Kuznets, 1955), based on the historical evidence of developed economies, suggests that a country's income inequality tend to rise in the initial stages of industrialization, reach the worst (most unequal) point at an intermediate levels of income, and then decline as the country moves onto high income levels. Correspondingly, the Gini index would rise at first, and then fall back again, as the economy gets developed. The post-war experiences of some developing economies, especially those in Latin America, suggests that the most challenging stage of economic development is the intermediate level of income or the bottom part of the inverted U. With large, persistent income disparity, a developing economy could get stuck in the bottom part of the inverted $U$ after initial rapid economic growth and have a hard time moving onto high- income level. On the other hand, the East Asian high performing economies (Note 1) exhibited a different trend in income distribution during their high-growth period between mid-1960s and 1990 (World Bank, 1993). By the World Bank and other studies, a positive association between GDP growth and improving equality was recorded in these economies during the period. Among them, the Four Tigers, Hong Kong, Singapore, Taiwan and South Korea, subsequently succeeded in moving onto high-income levels, without being caught by the so-called 'middle-income trap'.

China's economic growth bears many similarities with that of the Tiger economies, including export orientation, high savings rates, high investment rates and initial specialization in labour-intensive manufacturing and so on. Nonetheless, in terms of income distribution, the Chinese economy has not yet exhibited the positive feature as shown by the East Asian high performers. In other words, the Chinese high GDP growth has not been associated 
with improving income equality so far. From the sizeable literature on China's income distribution, the overall income disparity in the Chinese economy has increased steadily in the past three decades. Currently, a key issue or challenge is whether the income disparity will continue to widen, as the Chinese economy moves into the middle-income stage.

This paper discusses the recent trends in China's income distribution, with a focus on the interplay of the regional income disparity and rural-urban inequality. Section 2 compares the trends in income distribution between the Chinese economy and two Tiger economies, South Korea and Taiwan, in their respected high-growth periods. Section 3 analyses the recent trends in regional income disparity in China. Section 4 analyses the recent trends in urban-rural income disparity in the Chinese economy. Section 5 summaries the findings and discuss the implications.

\section{A Comparison with the Cases of South Korea and Taiwan}

The 'Four Tigers', namely, Hong Kong, Singapore, Taiwan and South Korea, all experienced rapid per capita GDP growth yet declining income inequality during the period from 1965 to 1990, as the World Bank and other studies showed. The relatively equitable income distribution during the high-growth period later contributed to their eventual success in turning into high-income economies. As Hong Kong and Singapore are not quite comparable to the Chinese economy that has a large rural population and diversified regions, the case of China will be compared with only the cases of South Korea and Taiwan here. Similar to South Korea and Taiwan in their high growth periods, China is in the process of shifting to an industrial economy from a dualistic developing economy characterized by deep urban-rural divide.

Figure 1 presents the Gini Indexes for Taiwan and South Korea for the period between 1964 and 1989, during which these two economies experienced rapid real GDP growth. As the figure shows, both of them maintained a stable and low Gini index during the two and a half decades. During the period, Taiwan's Gini fell from 32.5 in 1964 to 30.3 in 1989, and South Korea's Gini fell from 34.4 in 1965 to 33.6 in 1988.

Figure 2 presents the trends in the income distribution in the Chinese economy during the period from 1980 to 2004 by two indicators: the Gini index and the income-share ratio, namely, the ratio of the income share of the richest fifth of the population to the income share of the poorest fifth. The period between 1980 and 2004 was chosen because China's high growth started in 1978 when the country began making the transition to market economy. Thus, the period of 1980-2004 for China is comparable to the 1964-89 period for the Asian Tigers. As shown in Figure 2, there had been a rising trend in income disparity in the Chinese economy from 1980 to 2004. China's Gini index increased from 32 in 1980 to 46.9 in 2004, and in the same fashion, the income-share ratio in the Chinese economy increased from 4.6 in 1980 to 12.2 in 2004. Both indicators point to a worsening of income distribution during China's high growth period.

In explaining the divergence in income distribution between China and the two Tiger economies in their respected high-growth periods, one could refer to the difference in the starting institutional conditions. Unlike South Korea and Taiwan that launched industrialization from the basis of traditional markets, China started its high-growth period from the basis of a centrally planned economy, which typically had lower income inequality than market economies. Thus, the increase in the Gini index of China since its economic transition could be interpreted as a normal adjustment to market economy. This argument might be valid when comparing China with many other developing economies, but it cannot quite explain the difference in income distribution between China and the two Tiger economies. As shown in Figure 1, South Korea and Taiwan also had low inequality at the onset of their high-growth period -- their Gini Indexes were both in the low 30s around the mid 1960s. Yet, in both economies the Gini Indexes were kept at low 30s after two and half decades of rapid GDP growth. In contrast, China's Gini Index rose to upper 40s during the high growth period.

There have been extensive studies on the growth-equity patterns of Taiwan and South Korea in their 'take-off' periods (e.g. Fei and Ranis, 1975; Fei et al., 1978; Wade, 1990; World Bank, 1993; Birdsall et al., 1995; You, 1998; Jomo, 2006). By these studies, a key factor responsible for the low inequality in the two Tiger economies was the equitable landholdings in the rural sector enabled by the land reforms in the late 1940s and early 1950s. In Taiwan, the government exchanged state-company shares with landlords for farmlands and distributed the land to peasants at low prices. In South Korea, the government acquired land from landlords and resold it at subsidized price to tenants (see World Bank, 1993). The egalitarian pattern of asset-ownership in the rural sector led to a relatively equal distribution of rural income, which stood as an 'equalizer' for the overall income distribution by ameliorating the rise of income inequality in the urban sector in the process of rapid industrialization (Fei and Ranis, 1975; Fei et al., 1978). 
Rapid rise of rural income as a whole served as another 'equalizer' for the overall income distribution in the two Tiger economies. It is essential that the growth of rural income keep pace with that of urban income in the process of industrialization for dualistic developing economies like Taiwan and South Korea back then. From the research literature, in addition to the equitable landholdings, the adoption of new agricultural technologies and promotion of off-farm or non-agricultural activities in rural areas both contributed to the steady rise of rural income in Taiwan and South Korea (Fei et al., 1978; You, 1998; Jomo, 2006). In particular, the expansion of spatially dispersed rural industries and services played an important role in boosting rural employment and enhancing rural household income.

Other contributing factors to the virtuous growth-equity pattern in Taiwan and South Korea, which were cited in various studies, include rapid accumulation of physical and human capital, rapid expansion of employment, as well as effective corporation between the government and farmers' organizations (Wade, 1990; World Bank, 1993; Birdsall et al., 1995; You, 1998; Burmeister et al., 2001).

Briefly, the cases of South Korea and Taiwan provide a useful perspective for examining the problems of income distribution in China. As a dualistic developing economy in the shift to industrial economy, China is currently faced with challenges similar to that of the two Tiger economies in the past, in terms of income distribution. The experiences of South Korea and Taiwan could be helpful. There are two major dimensions of income distribution in China: urban-rural income disparity and regional income disparity. Urban-rural income disparity remains the central source of the overall income inequality in China, reflecting the main feature of a dualistic developing economy. Meanwhile, regional disparity has also been an important issue for China, due to the diversified geographic regions. Regional disparity and urban-rural inequality are closely intertwined in the Chinese economy. The following sections will examine the recent trends in each of the dimensions in details.

\section{Recent Trends in Regional Income Disparity}

The widening of the regional income disparity in the Chinese economy has received a great deal of attention in both academic research and policy-making since the early years of the reform. The studies mostly focus on the rising disparities between the coastal and inland regions rather than the inter-province disparities. Among the major factors that contributed to the widening of the regional gaps, the previous studies found FDI, labor migration, education, governmental preferential policies, SOE reform, fiscal decentralization, and public infrastructure and so on (Kanbur and Zhang, 1999; Yao and zhao, 2001; Demurger et al., 2002; Cai et al., 2002; Wang and Fan, 2004).

Although the regional income disparity has increased rapidly throughout the 1980s and 1990s, more recent studies showed that the rate of the increase has slowed since 2000 (e.g. $\mathrm{Xu}$ and Li, 2006). And regional disparities have declined in 2004 and 2005, measured by per capita GDP and household consumption ( $\mathrm{Li}$ and Xu, 2008).

To examine the trends in regional income disparity in recent years, this paper employs per capita income ratio as the measure for the income gaps among regions. Three sets of income ratios are calculated for the period from 2000 to 2009, based on the latest data from the NBS (National Bureau of Statistics of China). Among the four geographic regions in China, we focus on the income gap between the eastern or coastal region, the richest, and western or inland region, the poorest one (Note 2). Table 1 presents the eastern-western per capita GDP ratio in column one, the eastern-western per capita income ratio for urban households in column two and eastern-western per capita income ratio in rural areas in column three.

From Table 1, the overall income disparity between the eastern and western regions, as measured by per capita GDP ratio, has exhibited a declining trend from 2000 to 2009. Per capita GDP in the eastern region was 3.09 times that of the western region in 2000, and the ratio fell to 2.36 in 2009. Decomposing the regional disparity into urban and rural areas, the eastern-western income gap narrowed in the rural areas yet widened in the urban areas during the period. As column three shows, the eastern-western per capita income ratio for rural households fell from 2.2 in 2000 to 1.87 in 2009 . Nonetheless, the urban per capita income ratio increased slightly from 1.43 in 2000 to 1.47 in 2009 , as shown in column two.

As studies showed, income disparities among regions in the Chinese economy are driven mainly by the variations in degree of urbanization among regions and the differentials in rural income among regions (Huang and Luo, 2008; Luo and Zhu 2008). The first factor is directly linked to the urban-rural income disparity in China. As urban households have much higher income than rural households, the higher urbanization rate (Note 3 ) in the eastern region made it much richer than the western region. Secondly, rural income diverged among regions as well. Rural households in the eastern region generally make more income than their counterparts in the western region, which also contributed to the income disparity between the two regions. 
From this perspective, the concerted efforts of developing the western provinces launched by the Chinese government since 2000, including central government's initiatives of the Western Area Development Strategy, and specific policy measures taken at provincial level, has certainly played an important role in the trend of declining regional income disparity as identified in Table 1 . The programs of investment and infrastructure construction in the western region accelerated the urbanization process in the western provinces. The urbanization rate for the western region increased from $28.7 \%$ in 2000 to $39.3 \%$ in 2009 , greatly boosting the overall income of the region. Moreover, the policy efforts also led to a faster increase in the rural household income in the western region. From 2000 to 2009, rural per capita income in the western region grew at an average rate of $7.5 \%$ per annum in real term, exceeding the average rate of $4.6 \%$ per annum for the period between 1990 and 2000. In addition to the acceleration of urbanization and rural income growth in the western provinces, other factors may also have contributed to the narrowing of the regional income disparity in recent years. For instance, the surging demand for energy and resources, resultant from the continually rapid economic expansion, was in favour of the factor endowments of the western region.

In the meantime, the numbers in Table 1 also raised some concerns about the otherwise optimistic trends of improving regional disparity. The first one is about the rising urban income gap between the two regions. As mentioned above, the eastern-western per capita income ratio in urban areas increased from 1.43 in 2000 to 1.52 in 2005. Although the ratio fell back in 2009, but remained higher than in 2000. As the urbanization proceeds in the Chinese economy, the urban income gap among regions will become an increasingly important component for the overall regional disparity. Therefore, a rising urban income gap between the rich and poor region could worsen the overall income disparity between the two, despite the increase of the urbanization rate in the latter.

Another concern is about the slowdown of rural income growth in the eastern region during the period. As mentioned above, a faster growth of rural income in the western region contributed to the narrowing of rural income gap between the two regions. On the other hand, attributable to the smaller rural gap, was also a slower growth of rural income in the eastern region. From 2000 to 2009, rural per capita income in eastern region grew at an average rate of $5.6 \%$ per annum in real term, slower than the annual growth of $6.8 \%$ for the previous period between 1990 and 2000. Given the rapid growth of urban income in the eastern region, a slowdown in rural income growth would also widen urban-rural income gap in the region, which will be further discussed in Section 4.

\section{Recent Trends in Urban-rural Income Inequality}

We now turn to the urban-rural income inequality. Figure 3 shows the nationwide trends in urban and rural household income from 1980 to 2009. Both urban and rural per capita income surged tremendously in the past three decades, with the former rising 36 folds and the latter, 27 folds in nominal terms during the period. However, associated with the rapid income growth, the income differentials between the urban and rural households also increased rapidly. In 1980, urban per capita income was 2.5 times rural per capita income, and ratio increased to 3.33 in 2009. This trend of widening urban-rural income gap is consistent with the rising Gini index in the Chinese economy shown in Figure 2. As many studies suggested, the urban-rural income inequality remains the major source for the overall income disparity in China (e.g. Wei and Wu, 2001; Lin and Liu 2003; UNDP, 2005).

Figure 3 together with Figure 2 also revealed a close correlation in the direction of the movements between the urban-rural income ratio and Gini Index in the Chinese economy. From the Figure 3 data, the urban-rural income ratio fell initially from 2.5 in 1980 to 1.86 in 1985, and then started rising hereafter. Correspondingly, China's Gini Index fell from 32 in 1980 to 25.7 in 1984, then the trend reversed ever since, as shown by the Figure 2 data. Again, this correlation brings out the importance of the urban-rural divide in driving the overall income distribution in China. The brief move of narrowing urban-rural gap in the early1980s was mainly due to the success of the agriculture reform implemented in the early period of the transition, as documented by the literature on the Chinese economic transition. The Household Responsibility System had raised the rural income relative to the urban income during the period. Unfortunately, this positive tendency did not continue, and the urban-rural gap widened again as the reform focus shifted to the urban areas in later years.

To examine the interplay between the urban-rural income inequality and regional disparity more closely, Table 2 presents the urban-rural per capita income ratio in each of the four Chinese regions from 2000 to 2009. As the table shows, the western region, the poorest region, had the largest urban-rural income gaps, followed by the central region, and then, the eastern region. The northeast region that had lower income but the smaller urban-rural gap than the eastern region is rather an exception. The north-eastern region used to be the country's heavy-industry base in the planning era, and had a harder time making the transition to markets. Thus, the region's smaller urban-rural income gap, as a lingering legacy from the planning era, reflects the region's lower urban income rather than higher rural income, when compared with the eastern region. 
While the urban-rural income inequality increased in all four regions during the period, the rate of increase differed among the regions, as shown in Table 2. The north-eastern region saw the fastest increase in the urban-rural income ratio during the period, which, again, mostly reflects the region's 'catch-up' in the market transition in recent years. On the other hand, the urban-rural income ratio in the western region increased at the slowest rate among the four regions in during the period. This trend is consistent with the findings in section 3. A faster growth of rural income in the western region (than the previous period) had certainly helped slow the expansion of the urban-rural gap in the region.

On the other hand, a rather troublesome trend is the fast widening of the urban-rural inequality in the eastern region, the richest region. As shown in Table 2, the urban-rural per capita income ratio in the region increased from 2.26 in 2000 to 2.93 in 2009, a rate faster not only than the corresponding rate in the western region, but also than that in the central region. This trend contradicts the findings of some previous studies on the subject. For instance, Dwayne Benjamin et al. studied the income inequality in China from 1987 to 2002, and found that the urban-rural inequality increased more rapidly in inland or western region than in the coastal or eastern region (Benjamin et al. 2008). By these studies, an important reason for the slower widening of the urban-rural gap in the eastern region was the expansion of the non-state sector in the rural areas of the region (Wang, 2004; Brandt et al., 2008). In particular, the expansion of the TVEs (township and village enterprises) in 1980s and the early 1990s helped boost the rural income in the eastern region during the period.

To a great extent, the faster widening of urban-rural gap in the eastern region between 2000 and 2009 suggests a change of growth dynamics in the eastern region in more recent years. On the one hand, the growth of rural household income in the region slowed in more recent years. As known, the TVEs lost competitive position around the mid-1990s for various reasons. Rural per capita income in the eastern region slowed to an average rate of 5.6\% per annum between 2000 and 2009 from the annual growth of $6.8 \%$ in the period between 1990 and 2000, as discussed in Section 3. On the other hand, with the deepening of urbanization, real estate development has become one of the growth engines in the advanced eastern region in more recent years. The income distribution mechanism associated with the real estate boom in the coastal cities tends to reward developers and related businesses in the cities. As some studies suggested, the villagers and peasants, in some cases, were subject to the expropriation of land-lease contracts by developers and corrupted local officials (Zhang, 2006; Lindbeck, 2008). Insecure landholdings of villagers would discourage agricultural production and thus, slow the growth of rural income. The new round of growth in the eastern region may also have brought about other developments that favoured the city dwellers more than the villagers. For instance, the increase in the skill contents of industrial jobs tends to raise the payments to urban professionals, leaving peasants' earnings further behind. From the Table 2 data, the growth of urban per capita income in eastern region accelerated to an average rate of $9.4 \%$ per annum in real term during the period between 2000 and 2009, far exceeding the annual growth of the rural income in the region during the same period.

From the above, the urban-rural income inequality appeared to be more entrenched or persistent than the regional income disparity in the Chinese economy. It is difficult to reduce the urban-rural disparity, even with active income-redistribution and transfer payment policies, in the face of the speedy expansion of the urban sector in the modernization process.

\section{Concluding Remarks}

This paper examines the recent trends in regional income disparity and urban-rural income inequality in the Chinese economy, using per capita GDP and household per capita income as the measures. It finds that regional income disparity had declined during the period between 2000 and 2009, but the urban-rural income disparity continued to widen during the period.

The improvement of the regional income disparity was attributable to both an acceleration of urbanization and a faster growth of rural income in the western region, thanks to the government's concerted policy efforts. However, while the overall eastern-western income disparity declined, the urban income gap between the two regions had widened. The widening urban income gap among regions raises a concern, as it can sustain or worsen the overall regional disparity despite the proceeding of urbanization in the poorer regions.

The urban-rural income disparity appeared to be more entrenched than the regional income disparity in the Chinese economy. The paper finds that the urban-rural income disparity increased in all four regions during the period. Additionally, the urban-rural income disparity increased more rapidly in the eastern region than in the western and the central regions. Accounting for the faster deterioration of urban-rural inequality in the eastern region was a slowdown of the rural income growth, coupled with high urban-income growth in the region. It indicates that the 
income distribution mechanism in the economically advanced provinces in China might have turned even more in favour of the urban sector in recent years.

From a broad view, income distribution remains a key challenge for China to move beyond the 'middle-income' trap, and the narrowing of the urban-rural disparity holds the key for improving the overall income distribution in the Chinese economy. The ongoing industrialization tends to increase the returns to industrial and commercial capital, which favours the growth of urban income as a whole. To counteract the negative effects on overall income distribution, it is necessary that rural income growth keeps up with the increases in urban income.

In terms of how to enhance rural income, the experiences of the two Tiger economies offered useful implications. Government's direct investment in agricultural technologies, education and infrastructure projects in rural areas is surely important. Yet, farmers' own initiatives are also indispensable in developing a dynamic agricultural sector in long term. The most important incentive for farmers is secure equitable holding of farmlands. The security of land rights remains the key in stimulating agricultural outputs, encouraging villagers' investment in new farming technologies and improving agricultural productivities. From this perspective, policy measures on protections of villagers against the expropriation of farmlands carry long-term benefits to the economy.

The other implication is about the importance of rural industries and services in enhancing rural household income. Small-scale rural industries and services are effective in generating employment in local villages at relatively low wages. They are also flexible in adapting to new business opportunities, with low level of starting capital. Revenues from off-farm activities should take gradually larger share in total rural income, with the rise of agricultural productivities. Policy supports are certainly needed for the development of rural industries and services at this stage.

\section{References}

Benjamin, D., Brandt, L., Giles, J. and Wang, S. (2008). Income Inequality During China's Economic Transition. In L. Brandt \& T. Rawski (Eds.). China's Great Economic Transition (pp.728-775). New York: Cambridge University Press.

Birdsall, N., Ross, D. and Sabot. R. (1995). Inequality and Growth Reconsidered: Lessons from East Asia. World Bank Economic Review, 9 (3): 477-508. http://dx.doi.org/10.1093/wber/9.3.477

Brandt, L., Hsieh, C. and Zhu, X. (2008). Growth and Structural Transformation in China. In L. Brandt \& T. Rawski (Eds.). China's Great Economic Transition (pp.683-728). New York: Cambridge University Press. http://dx.doi.org/10.1017/CBO9780511754234.018

Burmeister, L., Ranis, G. and Wang, M. (2001). Group Behaviour and Development: A Comparison of Farmers' Organizations in South Korea and Taiwan. Yale University Economic Growth Centre Discussion Paper No. 828.

Cai, F., Wang, D. and Du, Y. (2002). Regional Disparity and Economic Growth in China: The Impact of Labor Market Distortions. China Economic Review, 13: 197-212. http://dx.doi.org/10.1016/S1043-951X(02)00072-X

Demurger, S., Sachs, J., Woo, W. T., Bao, S., Ahang, G. and Mellinger, A. (2002). Geography, Economic Policy, and Regional Development in China. Asian Economic Papers, 1(1):146-197. http://dx.doi.org/10.1162/153535102320264512

Fei, J. C. and Ranis, G. (1975). A model of growth and employment in the open dualistic economy: The cases of Korea and Taiwan. Journal of Development Studies, 11(2): 32-63. http://dx.doi.org/10.1080/00220387508421524

Fei, J. C., Ranis, G. and Kuo, S. W. Y. (1978). Growth and the Family Distribution of Income by Factor Components. The Quarterly Journal of Economics, 92(1): 17-53. http://dx.doi.org/10.2307/1885997

Huang, Y. and Luo, X. (2008). Reshaping Economic Geography in China. In Y. Huang and A. M. Bocchi (Eds.). Reshaping Economic Geography in East Asia (pp.196-217). Washington, D.C.: The World Bank. http://dx.doi.org/10.1596/978-0-8213-7641-6

Jamo, K.S. (2006). Growth with Equity in East Asia? DESA Working Paper No. 23.

Kanbur, R. and Zhang, X. (1999). Which Regional Inequality? The Evolution of Rural Urban and Inland-Coastal Inequality in China from 1983 to 1995. Journal of Comparative Economics, 27(4): 686-701. http://dx.doi.org/10.1006/jcec.1999.1612

Kutzet, S. (1955). Economic Growth and Income Inequality. American Economic Review, 45(1): 1-28.

Li, S. and Xu, Z. (2008). The Trend of Regional Income Disparity in the People's Republic of China. ADB(Asian Development Bank) Institute Discussion Paper No. 85. 
Lin, Y. and Liu. M. (2003). Growth Convergence and Income Distribution in China. The Journal of World Economy, 26(8): 3-14.

Lindbeck, A. (2008). Economic-social interaction in China. Economics of Transition, 16(1), 113-139. http://dx.doi.org/10.1111/j.1468-0351.2007.00315.x

Luo, X. and Zhu, N. (2008). Rising Income Inequality in China: A Race to the Top. The World Bank Policy Research Working Paper. WPS 4700.

National Bureau of Statistics of China (NBS). China Statistical Yearbook, various years. Beijing: China Statistical Publishing House. [Online] Available: http://www.stats.gov.cn/tjsj/ndsj/

UNDP. (2005). China: China Human Development Report. New York: Oxford University Press.

Wade, R. H. (1990). Governing the Market: Economic Theory and the Role of Government in East Asia's Industrialization. Princeton: Princeton University Press.

Wang, G. (2004). Accounting for Income Inequality in Rural China: A Regression Based Approach. Economic Research, 21(8): 117-126.

Wang, X. and Fan, G. (2004). Analysis on the Regional Disparity in China and the Influential Factors. Economic Research, 21(1): 33-43.

Wei, S. J. and Wu, Y. (2001). Globalization and Inequality: Evidence from China. NBER (National Bureau of Economic Research) Working Paper Series, No. 8611.

World Bank. (1993). The East Asian Miracle, Economic Growth and Public Policy. Washington, D.C.: the World Bank.

World Bank. (2010). World Development Indicator. Washington, D.C.: The World Bank.

Xu, Z. and Li, S. (2006). Analysis on the Trend of Regional Income Disparity in China. Economic Research, 23(7): 106-116.

Yang, D. T. (2002). What has Caused Regional Inequality in China? China Economic Review, 13(4): 331-334. http://dx.doi.org/10.1016/S1043-951X(02)00088-3

Yao, S. and Zhang, Z. (2001). On Regional Inequality and Diverging Clubs: A Case Study of Contemporary China. Journal of Comparative Economics, 29(3): 466-484. http://dx.doi.org/10.1006/jcec.2001.1726

You, J. (1998). Income Distribution and Growth in East Asia. Journal of Development Studies, 34(6): 37-65. http://dx.doi.org/10.1080/00220389808422545

Zhang, X. (2006). Asymmetric Property Rights in China's Economic Growth. IFPRI (International Food Policy Research Institute) Discussion Paper, No.28.

\section{Notes}

Note 1. The Word Bank's research report in 1993 covered eight high-performing East Asian economies (HPEA): Japan; the "Four Tigers," Hong Kong, Singapore, Taiwan and South Korea; and the three newly industrializing economies (NIEs) of Southeast Asia, Thailand, Indonesia and Malaysia.

Note 2. The eastern region includes 10 provinces and municipalities on the east coast of PRC and western region include 12 provinces in the inland of PRC.

Note 3. Urbanization rate is the ratio of urban population to total population. 
Table 1. Income Disparity between Eastern and Western regions, 2000-2009

\begin{tabular}{|l|r|r|r|}
\hline Year & Per capita GDP ratio & $\begin{array}{l}\text { Per capita income } \\
\text { ratio in urban area }\end{array}$ & $\begin{array}{l}\text { Per capita income } \\
\text { ratio in rural area }\end{array}$ \\
\hline 2000 & 3.09 & 1.43 & 2.20 \\
\hline 2005 & 2.79 & 1.52 & 1.98 \\
\hline 2007 & 2.63 & 1.50 & 1.93 \\
\hline 2009 & 2.36 & 1.47 & 1.87 \\
\hline
\end{tabular}

Sources: Authors' computation, based on data from National Bureau of Statistics of China.

Note: Per capita income in urban area is per capita disposable income for urban households. Per capita income rural area is per capita net income for rural households. Both are in current prices.

Table 2. Urban-rural per capita income ratio by region, 2000-2009

\begin{tabular}{|l|c|c|c|c|}
\hline Year\Region & Eastern & Northeastern & Central & Western \\
\hline 2000 & 2.26 & 1.49 & 2.55 & 3.46 \\
\hline 2005 & 2.83 & 2.58 & 2.98 & 3.69 \\
\hline 2007 & 2.90 & 2.64 & 3.03 & 3.73 \\
\hline 2009 & 2.93 & 2.63 & 3.00 & 3.72 \\
\hline
\end{tabular}

Sources: Authors' computation, based on data from National Bureau of Statistics of China.

Note: Per capita income in urban area is per capita disposable income for urban households. Per capita income rural area is per capita net income for rural households. Both are in current prices.

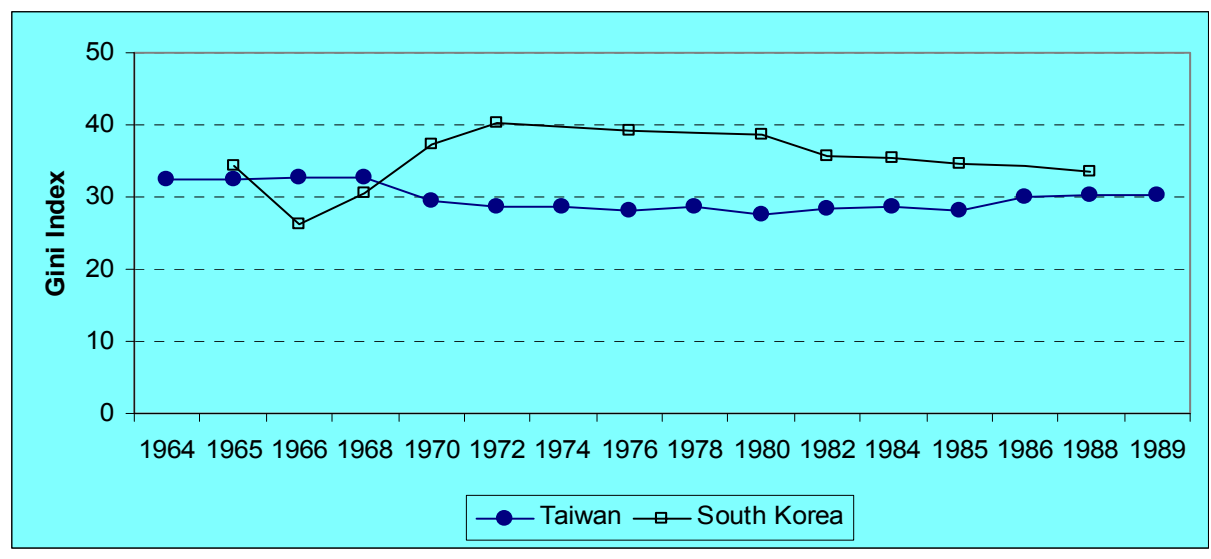

Figure 1. Gini Index, South Korea and Taiwan, 1964-1989

Sources: The UNU-WIDER World Income Inequality Database (WIID) 


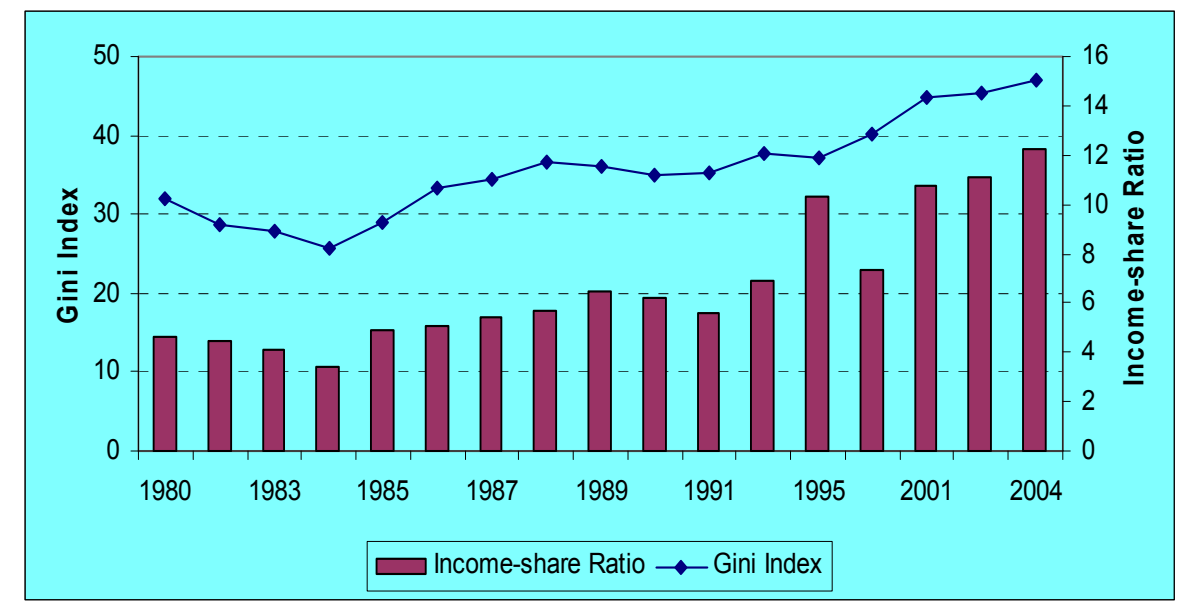

Figure 2. Gini Index and Income-share Ratio, China, 1980-2004

Sources: The UNU-WIDER World Income Inequality Database (WIID).

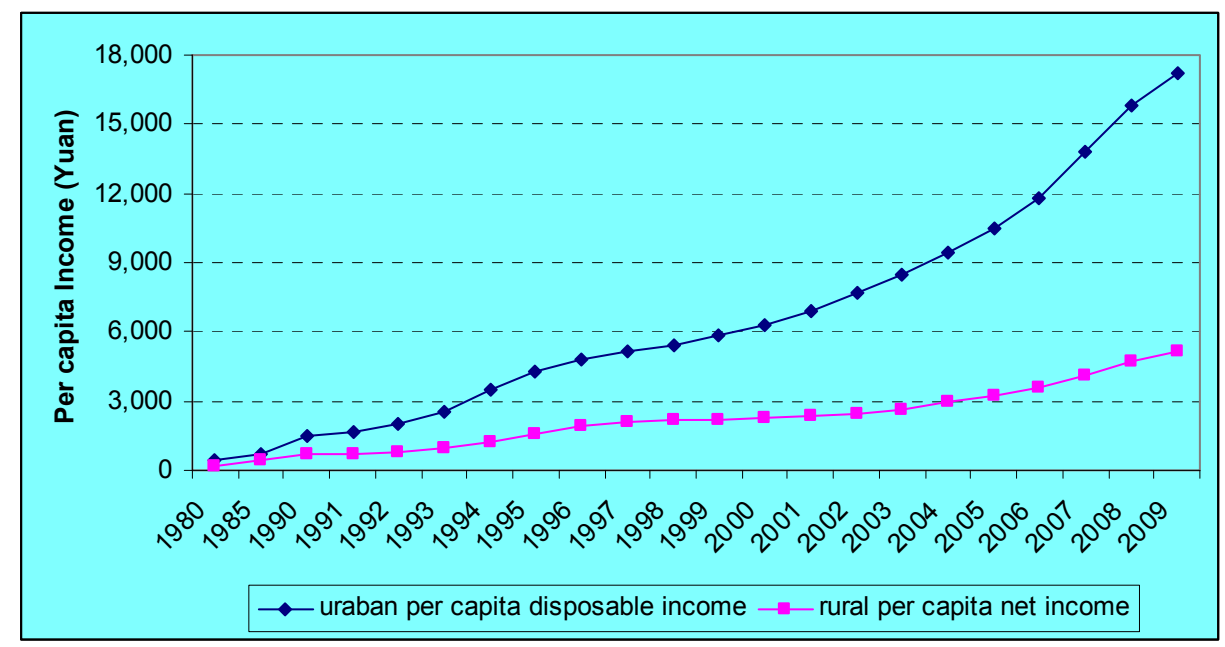

Figure 3. Urban and Rural Per Capita Income, 1980-2009

Sources: National Bureau of Statistics of China. 